\title{
O transtorno de estresse pós-traumático nos contextos de trabalho: reflexões em torno de um caso clínico
}

\author{
Júlia Nogueira Dorigo ${ }^{1}$ e Maria Elizabeth Antunes Lima ${ }^{2}$
}

\begin{abstract}
$\mathrm{O}$ artigo trata de uma das diversas formas de adoecimento mental observadas nos contextos de trabalho: o transtorno de estresse pós-traumático (TEPT). Para isso, foi analisado o caso de um trabalhador acometido por TEPT a partir dos principais teóricos que trataram do assunto. Trata-se de um vigilante que, por cinco anos, conviveu com o transtorno sem saber o que o acometia e sem ser devidamente tratado pela equipe médica e psicológica de sua empresa. Com o artigo, pretende-se contribuir para o avanço na compreensão dessa grave doença, focalizando suas causas, os sintomas que a compõem e as possibilidades de prevenção.
\end{abstract}

Palavras-chave: Saúde mental e trabalho, Transtorno de estresse pós-traumático, Estudo de caso.

Posttraumatic stress disorder in the work contexts: reflections around a clinical study case

This article is about one of the diverse kinds of mental disorders observed in the labor context: the posttraumatic stress disorder (PTSD). For that was analyzed one case, about a worker diagnosed with PTSD, based on the theoretical principles concerning it. This is a case of a vigilant that, for five year, lived with the disorder without being correctly treated by his employee medical and psychological team. Our article intend to contribute to moving forward in comprehending this disorder, focusing in its causes, his symptoms, and the prevention possibilities.

Keywords: Work and mental health, Posttraumatic stress disorder, Case study.

\section{Introdução}

$\mathrm{O}$ presente artigo pretende contribuir para a discussão sobre um tipo de adoecimento mental que, embora diagnosticado há várias décadas, tem aparecido com maior freqüência em alguns contextos de trabalho, o transtorno de estresse pós-traumático (TEPT).

Para subsidiar nossa análise, apresentaremos um estudo de caso realizado no Serviço de Psicologia Aplicada (SPA) da Universidade Federal de Minas Gerais (UFMG). Trata-se de um trabalhador que chegou até nossa equipe de Saúde Mental e Trabalho (SM\&T) solicitando um diagnóstico para ser encaminhado ao Instituto Nacional do Seguro Social (INSS). Sua demanda consistia na verificação de um possível nexo entre seus problemas de saúde e a última atividade profissional que exerceu.

Decidimos utilizar o Método Biográfico, proposto por Louis Le Guillant (2006), pois concordamos com esse autor quando afirma ser essa a melhor abordagem para o estabelecimento do nexo entre o adoecimento e as condições de vida e de trabalho. ${ }^{3} \mathrm{O}$ relato do caso foi ilustrado com trechos do depoimento do próprio paciente, pois entendemos que

\footnotetext{
1 Mestranda em psicologia pela Universidade Federal de Minas Gerais, psicóloga graduada pela mesma universidade. Faz parte do Laboratório de Extensão, Estudos e Pesquisa em Psicologia do Trabalho.

2 Professora adjunta do Departamento de Psicologia da Universidade Federal de Minas Gerais. Núcleo de Saúde Mental e Trabalho.

$3 \mathrm{Na}$ verdade, esse método pode ser adotado em qualquer abordagem clínica, pois consiste no resgate minucioso da história do sujeito, visando compreender sua trajetória pessoal e o papel das suas condições concretas de existência na gênese dos sintomas que apresenta.
} 
sua percepção sobre os fatos é essencial e dificilmente poderia ser substituída por qualquer outra análise. A esse respeito, Le Guillant disse:

Esta linguagem popular, fruto de uma experiência individual e coletiva, direta e insubstituível, parece-me mais adequada do que qualquer outra que fosse feita "do exterior", ou em termos mais "científicos" suscetíveis de evocar a realidade, para tornar perceptíveis os aspectos sensíveis de situações que escapam sempre, em parte, àqueles que não a vivenciaram $(2006$, p. 332).

\section{O acolhimento de João ${ }^{4}$}

João apresentou-se como vigilante no nosso serviço, em setembro de 2004, dizendo que trabalhava em uma firma prestadora de serviços em Belo Horizonte. Em 1999, no período de apenas um mês, ele havia sofrido três assaltos no seu posto de serviço e, desde então, começou a apresentar sérias mudanças em seu comportamento. Foi afastado algumas vezes do trabalho, retornando sempre para a mesma atividade por determinação da empresa e do INSS.

Em 2004, procurou auxílio junto ao sindicato de trabalhadores metalúrgicos de Betim, que o encaminhou para nossa equipe. ${ }^{5}$ Conforme já dissemos, ele necessitava obter uma CAT (Comunicação de Acidente de Trabalho), com a qual tentaria pleitear seus direitos junto à previdência. Naquele momento, encontrava-se afastado de suas atividades de trabalho havia quase um ano e recebia, pela segunda vez, um auxílio-doença. ${ }^{6}$

No momento em que iniciamos seu atendimento, João já se encontrava em melhores condições psíquicas. Tanto sua mãe, quanto ele reconheceram que sua melhora foi significativa, tendo em vista o quadro anterior. Ele já não se isolava em casa, conseguindo manter algum convívio com amigos ou vizinhos do prédio onde morava. Não apresentava mais delírios de perseguição e conseguia discorrer, com senso crítico, sobre alguns episódios da época posterior aos assaltos sofridos em sua atividade como vigilante. Isso fica claro na fala de sua mãe: "agora, ele tá bom, perto do que ele teve".

Mas João ainda não se via totalmente recuperado. As imagens dos assaltos ainda eram muito vivas. As sensações suscitadas pela experiência e o medo que adquiriu de trabalhar como vigilante ainda estavam muito presentes. Bastava recordar as antigas atividades ou falar sobre o que sentiu durante os assaltos para começar a apresentar os mesmos sintomas manifestados naqueles momentos de grande tensão, sobretudo o suor nas mãos.

\footnotetext{
4 Trata-se de um nome fictício.

5 O Sindicato dos Trabalhadores Metalúrgicos de Betim, cidade próxima a Belo Horizonte, tornou-se uma referência em questões de saúde ocupacional, devido à parceria que estabeleceu com nossa equipe, na UFMG, resultando no atendimento de dezenas de trabalhadores com transtornos mentais. Com o passar do tempo, passou a ser procurado por trabalhadores pertencentes a outras categorias, como é o caso de João.

6 Desde o início, João foi informado de que a CAT não poderia ser emitida por um psicólogo, mas que seria atendido por um membro de nossa equipe, com o objetivo de investigar, de forma mais aprofundada, seu processo de adoecimento e, ao final, elaborar um laudo. Informamos também que, caso ficasse comprovado o nexo, esse laudo poderia ser útil na obtenção da CAT ou na reivindicação dos seus direitos.
} 


\section{A história de João}

João é o terceiro na ordem de nascimento de uma família com seis filhos. Ele descreve sua infância como uma fase boa de sua vida, durante a qual jogou muita bola e divertiu-se com os colegas, mas não deixa de frisar que também trabalhou muito. Entre suas obrigações, tinha a tarefa de cuidar dos irmãos mais novos enquanto a mãe trabalhava fora.

Seu pai, que era o segundo marido de sua mãe, saiu de casa quando tinha apenas cinco anos. Sobre ele, diz não ter quase nada a falar principalmente por ter desfrutado muito pouco de seu convívio, uma vez que, após a separação, praticamente não o viu. Admite ter sentido a falta da presença paterna, dizendo que sentia-se triste quando se comparava com as outras crianças. Apesar disso, considera que parte dessa lacuna foi preenchida por seu padrasto, pai dos irmãos mais novos.

Sua mãe também considera que sua infância foi tranqüila como a de "qualquer criança", dizendo que ele brincava com as irmãs mais velhas, era bom aluno e muito querido pelas professoras na escola. Ela também se referiu ao trabalho, dizendo que o filho sempre foi motivado para trabalhar: "Olha, ele sempre gostou de trabalhar muito, desde pequeno (...). O João foi entender por gente ele queria trabalhar (...). Ele tinha uma disposição para trabalhar fora do comum".

João conviveu bastante, durante um período de sua infância, com a avó materna, que cuidava dele e de seus irmãos enquanto a mãe trabalhava. Após o falecimento da avó, ele e as irmãs mais velhas passaram a ter a responsabilidade de cuidar dos irmãos mais novos. Referese a essa avó como uma pessoa muito querida, dizendo que morreu quando ele tinha oito anos, deixando muitas saudades.

Ele descreve seu relacionamento com a mãe como tranqüilo, dizendo que a admira por ser trabalhadora e por ter conseguido criar os seis filhos. Fala de todos os irmãos com muito carinho e sente falta das irmãs, que se casaram e passaram a morar em locais distantes. Essas irmãs são mais velhas que ele, mas têm idades próximas. Durante a infância, brincavam muito, mas também cuidavam uns dos outros, o que fez com que ficassem muito unidos.

$\mathrm{Na}$ ocasião do atendimento, seu irmão caçula estava preso por furto havia quatro anos. Quando ocorreu a prisão, João estava afastado pela primeira vez e ficou muito triste com o ocorrido, dizendo que o irmão havia acabado com sua vida.

Esse episódio teve um impacto importante sobre ele e, segundo sua mãe, agravou ainda mais seu quadro, deixando-o muito "abalado". Ele chorava e manifestava grande apreensão em relação ao futuro do irmão. Quando conseguiu uma certa estabilidade, passou a falar do problema ainda com tristeza, porém compreendendo-o melhor e tratando-o com mais tranqüilidade.

Além das duas irmãs casadas e do irmão que está com problemas com a justiça, João tem dois irmãos mais novos: uma irmã, que tinha, na época, dezenove anos, e um irmão de dezessete anos. Disse que se relacionava muito bem com os dois e que tentava cuidar deles. Estava tentando levá-los a uma empresa que promove a inserção de jovens no mercado de trabalho, como ele próprio fez no início de sua vida profissional.

Afirma que sempre teve um ótimo relacionamento com todos os irmãos, dizendo que o respeitavam e acrescentando que, quando era possível, ajudava-os em suas despesas pessoais. No momento das entrevistas, um deles estava sob sua responsabilidade, morando com ele, mas João esperava mudar para uma casa maior onde pudesse morar com toda a família. Ficou evidente que comportava-se como um pai frente aos irmãos mais novos, sentindo-se responsável por eles e manifestando sempre uma grande preocupação com seu futuro. 


\section{A história ocupacional pregressa}

João relata que sempre gostou de trabalhar e, como vimos, sua mãe confirma esse dado. Segundo ela, o filho, desde pequeno, era muito responsável, esforçando-se em conseguir alguma atividade que lhe permitisse ajudar nas despesas da casa. Seu primeiro emprego com carteira assinada foi aos dezesseis anos, em uma fábrica de sapatos, onde trabalhou três meses. Durante a seleção fez todos os exames médicos, testes psicológicos e foi considerado apto para exercer a atividade. Nessa empresa, trabalhava em esteiras de produção abrindo pontos de calçados e passando cola. Descreve esse trabalho como muito cansativo e submetido a muita pressão, por isso demitiu-se, preferindo tentar outra área. Entrou, então, no Centro Salesiano do Menor (CESAM), onde fez o curso de office-boy e, logo depois, começou a trabalhar: "Eu cheguei, tava novo ainda, fiz o curso (...), foi um dos melhores serviços que eu tive".

O CESAM é uma instituição religiosa que tem como finalidade a educação e evangelização de adolescentes carentes na faixa etária de dezesseis a dezoito anos. Ele os encaminha para o mercado de trabalho formal e os acompanha no desempenho de suas atividades.

Após realizar o curso, João foi encaminhado para uma empresa transportadora de valores, onde iniciou seu trabalho, fazendo transporte de dinheiro, pagamentos em banco e depósitos. Essa empresa faliu e fechou suas portas. Ele foi, então, para uma construtora na qual, ainda atuando como office-boy, transportava o pagamento semanal dos empregados.

Trabalhou como office-boy até completar dezoito anos, quando automaticamente teria que se desligar do CESAM. No entanto, antes de encerrar seu período na instituição, foi convidado por uma empresária para trabalhar em sua empresa de ônibus, onde continuaria exercendo a função de office-boy. Porém, relata que, ao chegar lá, foi encaminhado para a atividade de faxina: "Me chamou para trabalhar na empresa dela, que ela ia mandar o boy embora e tava precisando de outro. Chegando lá, ela me tacou na faxina".

Descontente com esse emprego, João decidiu pedir demissão, conseguindo rapidamente uma nova colocação. Assim, no mês seguinte, já estava trabalhando, sob contrato temporário, em uma delicatessen, montando cestas de Natal e carregando caixas. Logo em seguida, surgiu a oportunidade de trabalhar em uma empreiteira que prestava serviços para uma distribuidora de bebidas, onde permaneceu apenas durante o período de experiência para, em seguida, ser contratado pela própria distribuidora para a qual prestava serviços.

Ele descreve esse trabalho como muito pesado, pois trabalhava nos caminhões de entrega de bebidas, carregando e descarregando os engradados de cervejas ou refrigerantes, o que exigia muita força física. Mas diz que, ao mesmo tempo, era muito bom, pois se sentia bem tratado: "...era uma mãe de empresa para gente. Todo mundo gostava de lá".

Encerrou seu trabalho nessa distribuidora quando a empresa foi vendida, aparentemente por problemas financeiros. Resolveu, então, fazer um curso de preparação de vigilantes e tentar ingressar nesse ramo de atividade.

Ele descreveu assim o seu estado de saúde quando decidiu atuar na nova área: "Tava beleza, tava ótimo! Forte fisicamente, bem... e tava esperando completar os vinte e um anos para fazer o curso de vigilante. Guardei o dinheiro que precisava e fiz o curso".

Após fazer o curso, foi contratado e começou a trabalhar em uma empresa prestadora de serviços na área de vigilância, exercendo a função para a qual se preparou. Bastante animado, iniciou suas atividades como vigilante em uma estação de metrô: 
Eu cheguei lá, bem, muito alegre, porque eu comecei a trabalhar, porque eu tava precisando de um trabalho para ajudar a minha família nas despesas (...). Eu tava com vinte e dois anos, nessa época. Então, eu precisava trabalhar (...). Fiz o curso de vigilante, não tomei pau no psicotécnico, passei direto. Fiz, tava normal, como qualquer outro profissional, apto a trabalhar.

\section{O trabalho como vigilante}

João passou a trabalhar na empresa de vigilância em abril de 1999, iniciando suas atividades nas estações de metrô da capital.

Ele trabalhava no turno noturno, como folguista, ou seja, cobria as folgas dos outros vigilantes. Sendo assim, não tinha local fixo de trabalho. Os colegas trabalhavam quatro dias e folgavam um dia, sendo que João cobria essa folga atuando, a cada noite, em uma estação diferente.

Eu era folguista. Cada noite era uma estação. Então, eu passei pela central, comecei na central, passei pela Santa Efigênia, perto de uma via. Depois eu passei é... num lembro, eu trabalhei em várias, várias. Foi Carlos Prates, Calafate, Cidade Industrial e (...) a outra eu não me lembro.

Ao descrever sua rotina de trabalho, conta que sua jornada iniciava-se às vinte e duas horas horas, encerrando às sete horas da manhã seguinte. Ao chegar à estação, recebia, do colega que estava terminando o turno anterior, as chaves da estação, da portaria e da sala de vigilância. Só não recebia as chaves do cofre, pois essas não ficavam no local. Em seguida, conferia se tudo estava em ordem, assinava um caderno comunicando sua entrada e o recebimento das chaves e, a partir daquele momento, iniciava a vigilância da estação. Era responsável também pela vigilância por uma câmera de vídeo que registrava o que ocorria no pátio da estação, comunicando-se com o centro de comando durante a noite, caso necessário, e registrando no caderno de controle eventuais atividades realizadas pelos funcionários responsáveis pela revisão dos equipamentos e das ferrovias. Sua folga era de um dia por semana, variando de acordo com a empresa para a qual trabalhava.

Ele expôs, assim, sua rotina:

(...) Passar a estação é... O rapaz, todo mundo que tá largando o serviço, ele te mostra as chaves das portaria, dos lacre (...) Ficava lá, as chaves tudo que tinha, só não tinha a do cofre. E eu tinha que assinar, conferir tudo certinho, as chaves lá da portaria tudo, conferir certinho e assinar. E aí, a partir daquele momento, tudo que acontecia na madrugada.... porque eles ia lá para ver se a gente tava dormindo, para eles pegar, porque diz que se pegar dá até justa causa. Coisa que nunca aconteceu comigo. Ficava sempre acordado, porque eu era evangélico. Saía da igreja, já ia para estação, orava muito. Que era uma coisa muito arriscada, porque ficar numa estação onde muita gente passa, passava, de madrugada por ali, de madrugada, e podia vim pela via de onde que o trem passa. Ficava a câmera lá, aí a gente tinha que... monitorar as coisas lá.

Portanto, além de responsável pela segurança da estação à noite, ele também era controlado por um fiscal, que verificava se os vigilantes estavam acordados.

Outra atividade que desempenhava nas estações de metrô era a ronda entre uma estação e outra, utilizando um veículo, sempre que era convidado por outros vigilantes. Nesses momentos, portava uma arma de fogo. 
A ronda era dentro do carro da rede ferroviária. E fazia ronda para ver o que estava acontecendo (...) pela rua, pela avenida, que eles me deslocava de um local para outro (...). Eu ia com o carro, eles te davam o revólver, você colocava na cintura.

Assim, só utilizava armas de fogo durante essas rondas, já que, na época em que atuava nas estações de metrô, o vigilante não trabalhava armado.

João atuou, normalmente, durante oito meses como vigilante no metrô. Quando indagado como se sentia ao trabalhar nessa atividade, ele disse:

Foi bom demais! Porque eu me sentia igual a um soldado, todo fardado, de algema, cinturão, mas nada de.. porque a minha religião prega que a gente tem que ter amor pelo próximo, nada de fazer covardia (...). Um soldado, cumprindo seu papel, seu dever, para evitar o pior.

No entanto, conforme já foi dito, em dezembro de 1999, ele sofreu três assaltos em diferentes estações, sendo que todos ocorreram no curto período de um mês.

\section{Os assaltos}

João descreveu os três assaltos que sofreu, dizendo que o primeiro foi cometido por três menores de idade:

Chegaram bem armados e, foi lá, já me ameaçando, colocou a arma na minha coluna, assim, e falando, se eu mexesse eles iam atirar mesmo. Eu falei: "pelo amor de Deus, vocês pode fazer o que vocês quiser, mas não machuca ninguém, eu sou um pai de família, num machuca ninguém não". Aí, eles pegou e falou: "não, você fica na sua aí que nós vamos lá pegar o que nós tem que pegar!". Foram lá, roubou a bilheteria, roubou os ingressos, até, se eu não me engano, foi dessa vez que eles roubaram os funcionários de lá também, as bolsas dos funcionários.

Passados alguns dias, ocorreu o segundo assalto, dessa vez, cometido por adultos:

Então, aí, passaram mais uns dias, outro assalto. Aí, esses já parecia ser de maior. Aí, eles pegaram, assaltaram, chegaram lá, pressão psicológica de novo. Um chegou a me dar uma coronhada aí, falou: "cala a boca e tal, deita no chão e tal".

Como os dois assaltos ocorreram em seu horário de trabalho, algumas pessoas da empresa pareciam suspeitar de uma possível cumplicidade de João com os assaltantes:

(...) então, os assaltos, sempre assim nesse mesmo horário. Eu acho até que os pessoal chegou a desconfiar até de mim mesmo, que eu tava mandando os meninos assaltar lá. Foi uma pressão muito psicológica.

De fato, logo após o segundo assalto, alguns colegas manifestaram a desconfiança de que ele tivesse ligação com o ocorrido, chegando a levantar uma suspeita sobre sua provável relação com os assaltantes:

Eles falaram assim: "é, Silva", porque Silva é o meu nome de guerra lá na firma. "É, Silva, você tá trazendo os pessoal". Porque eu tava morando perto de uma vila, então, eu tava trazendo os pessoal da vila para assaltar a gente. Eu falei: "não, rapaz"... eu fiquei assim, não sabia nem o que falar com eles. 
O terceiro e último assalto parece ter sido o mais traumático de todos, conforme o relato de João:

O último assalto, foi lá na cidade industrial. O cara me jogou no chão assim e falou que se eu olhasse para cara dele ele atirava ni mim. Apontou a arma na minha cabeça o tempo todo. Sempre vinha de três ou de quatro pessoas. Uma vez de três, duas vezes de quatro. E, eles pegaram e, foi assim, sabe, aquela coisa toda, aquele pânico todo querendo a chave de cofre. $\mathrm{O}$ chefe de estação teve que falar com eles que o cofre não abria, que eles só iam lá para recolher dinheiro. Ia, recolhia dinheiro e levava a chave. E foi um pânico danado. Aí, eu não peguei ocorrência, não peguei nada porque eu não sabia de nada, tava todo desorientado.

Assim, João viveu momentos de muita tensão, principalmente, pelo fato de os assaltantes estarem armados e colocarem em risco sua vida e as de outras pessoas que se encontravam na estação.

Durante todos esses assaltos, sentiu-se muito ameaçado, com medo de morrer e desprotegido, chegando a levantar a hipótese de que aquilo era obra de algum inimigo seu:

Eu esfriava todo, eu ficava gelado tremendo. Eu achava que alguém tava me perseguindo, seja no... alguém que não gostava de mim, porque, às vezes, você tem inimigo também, no bairro.

Mas o que parece tê-lo afetado mais foi o fato de ter sido ameaçado de morte ou de sofrer um ferimento grave. Sobre a sua reação, nessa época, sua mãe conta:

Ah, ele reclamava de arma na cabeça, né? Muito, ele falava: "a senhora não sabe o que é ficar com a arma na cabeça, ser ameaçado de morte", "a senhora não sabe o que é ficar com a arma na coluna, pra mim ficar aleijado". Quando eu falava com ele: "ô meu filho, você tá exagerando, graças a Deus passou e não aconteceu nada", ai, ele ficava irritado, quando falava isso, ele ficava nervoso demais.

Além disso, não se pode desconsiderar o fato de que os três assaltos ocorreram em um período muito curto: "Eu nunca imaginaria que iria acontecer uns assaltos tão freqüentes comigo e com tanto pânico que eles colocaram na gente, em mim e em quem estava na estação".

\section{O surgimento e a evolução dos sintomas}

Após sofrer os três assaltos, João começou a apresentar alterações em seu comportamento, passando a não sentir-se bem no seu posto de trabalho e a desconfiar de que havia mesmo alguém o perseguindo:

...aí, depois do primeiro [assalto], eu falei: "ah, isso acontece e tal", veio o segundo e falaram:

"pô, mais você de novo?". Aí, veio o terceiro e eu desequilibrei geral. Isso tá tudo errado, eles estão me perseguindo, deve ser alguém aí, e já fiquei todo fora do normal.

Desde então não conseguiu exercer adequadamente suas atividades, sendo imediatamente afastado do trabalho, pois os médicos e os psicólogos da empresa perceberam que ele estava sem condições de trabalhar. Ele passou a apresentar sintomas graves, como delírios e alucinações:

Eu fiquei todo fora do normal e eles me tiraram do setor e me mandaram eu para firma e passar pelos médicos. Os médicos falou que eu não estava normal mesmo, que tinha que fazer 
tratamento no INPS, e eu fiquei vários períodos conversando com médicos. Conversava com médico uma coisa que não tinha nada a ver e eu mesmo não entendia o que eu tava falando. Eu fiquei todo pirado. Todo pirado, fora de mim mesmo.

...eu tentava melhorar, mas a minha reação era totalmente diferente, eu não conseguia nem falar direito com as pessoas, conversar direito.

Durante o período em que ficou afastado, logo após os assaltos, João começou a apresentar sintomas que chamaram a atenção de sua mãe. Ele passou a ficar muito isolado dentro de casa, não saía e, após algum tempo, recusava receber visitas, até mesmo da família. ${ }^{8}$

Foi depois dos assaltos. Sabe o que ele fazia? Eu mesma, quando eu chegava lá, e ele tava assim... espiando pela gretinha da porta. Assim, sem qualquer ação. Sem qualquer coisa. Eu já achava, assim, anormal o jeito que ele já tava ficando. Que foi gradativamente, não foi assim de uma vez não. Ele foi, já sentiu no início e, logo em seguida, foi aquelas perguntas toda, e aquela preocupação e o medo. Medo de voltar a acontecer de novo. Não queria ficar perto de mim. Aí, aceitava eu ir lá, mas chegou um ponto de não querer aceitar mais. Mas era uma dificuldade. Eu batia na porta... Chegou a dar até bicho nas vasilhas dele. De tanta dificuldade. Ele trancava a porta.

João passou a apresentar dificuldades para dormir, pois ficava pensando nos "perigos do mundo" e com medo do que poderia acontecer, sobretudo, se saísse de casa à noite. Diz ter ficado muito agitado e que, após algum tempo, teve de retornar para a casa da mãe. No entanto, a situação não mudou muito, pois continuou com dificuldade para dormir e, quando dormia, falava em voz alta, acordando a mãe: "...eu ficava em voz alta, falando todo dia à noite e não lembrava o que eu falei. Minha cabeça toda transtornada”.

Ele admite que chegou a pensar em se matar, dizendo que, se não fosse sua religião, teria feito isso, pois não via solução para o sofrimento pelo qual passava.

Alguns dos seus sintomas só são lembrados por sua mãe, que ficou impressionada com a gravidade do problema de que padecia o filho. Ele começou a apresentar delírios de cunho persecutório, dos quais não se lembra muito bem, embora reconheça que, naquele momento, não se encontrava bem psicologicamente. Dizia sempre que estava sendo perseguido e que tinham pessoas tentando fazer-lhe algum mal. Em outro momento, achou que a lagoa da Pampulha secava por sua causa. Sua mãe comenta o problema:

Às vezes, eu pegava ele rindo. Isso aconteceu duas vezes, pegar ele rindo de noite, de dia. Ele ria muito, sem motivo. Muitas vezes, ele tava com a televisão ligada, mas com o olho muito distante. Chegou a me deixar preocupada, né? Se ele era esquizofrênico, se ele era não sei o quê (...). Ele só ficava ausente, ou, então, em depressão... Ele só ficava quieto lá no quarto, nem conversava comigo, nem saía.

Um sintoma que chamou a atenção de sua mãe foi seu afastamento do convívio social. Segundo ela, João passou a ter medo de sair de casa e de conviver com outras pessoas. Por sentir-se perseguido, não conseguia confiar em mais ninguém e, assim, evitava todo tipo de contato. Isolou-se completamente, parando, inclusive, de falar sobre namoradas ou outros tipos de relacionamentos. Passou também a relaxar com os próprios cuidados pessoais, comportando-se de uma forma totalmente diferente de antes. Sua mãe descreve assim a situação:

Eu via ele sempre muito bem arrumado, porque ele era muito vaidoso. Agora, nem tanto, agora ele é muito arrumadinho, mas nem tanto (...). Muito alegre, fazia uns churrascos lá com os amigos, namorava, coisa que ele não tá fazendo, não tá fazendo até hoje (...) ele não tá

8 Cabe esclarecer que, nessa época, João já morava sozinho, pois estava, aos poucos, conquistando sua independência econômica e financeira. 
namorando, daí para cá. E, antes, ele namorava e passeava muito, ia nos pagodes. Agora, não. Agora, ele se fechou, se fechou.

As insinuações que João sofreu sobre sua cumplicidade com os assaltantes também o afetaram negativamente, fazendo com que se sentisse ainda mais perseguido. Sua mãe comenta esse problema:

Eu ficava com medo, ele só falava em suicidar. Que a vida dele tinha acabado, que eles estavam achando que ele era desonesto. Ele ficou muito sentido, com essas conversas que eles falaram, sabe? Eu tive vontade de ir lá na firma, brigar, procurar saber quem que falou.

Porque isso mexeu com ele muito mais, ou tanto quanto os ladróes.

Ela percebe claramente o impacto negativo que os assaltos tiveram na vida do filho: "Ele ficou muito deprimido, e sempre falando nos assaltos, sempre falando: 'que esses assaltantes acabou com a minha vida'...".

\section{O retorno ao trabalho}

Em fevereiro de 2003, depois de passar por mais uma perícia no INSS, João retornou ao trabalho de vigilante na mesma empresa. Na perícia, ele foi classificado como capacitado para voltar ao trabalho com algumas restrições, sendo que a restrição colocada pelo médico perito era quanto ao uso de armas de fogo.

Ele conta que queria muito voltar a trabalhar, pois precisava do dinheiro para ajudar em casa. Mas, para exercer suas funções, precisou que o médico da empresa o autorizasse a utilizar armas de fogo, pois, naquele momento, todos os vigilantes já as estavam usando, o que não acontecia na época dos assaltos.

Ao retornar, João foi colocado na reserva, ficando sem posto fixo de trabalho e à disposição da empresa, sendo deslocado para onde seus serviços fossem solicitados. Nesse período, foi encaminhado para trabalhar em cidades da região metropolitana de Belo Horizonte, para onde ia pela manhã e só retornava à noite. Foi também deslocado para condomínios próximos à periferia da cidade, dizendo não ter gostado muito e ter se sentido ameaçado pela comunidade local. Por último, cobria o horário de almoço de vigilantes nos bancos, assumindo seus postos, ficando ele mesmo, muitas vezes, sem almoçar.

Apesar de ter sido ele quem insistiu em retornar, diz que não se sentia muito bem no trabalho, especialmente por estar armado. Sentia muita insegurança e medo de que algo de errado acontecesse, suando frio, no rosto e nas mãos. Mesmo durante nossas entrevistas, ao se lembrar desses acontecimentos, começava a sentir as mãos frias e suadas. Além disso, ele não se sentia preparado para lidar com as novas exigências, o que aumentava ainda mais sua ansiedade:

...sem contar o medo, de você tá no setor, você tá armado e vem as pessoas com ignorância para cima de você, você fica todo desabalado no momento. Nem que seja coisa de minuto, mas ficava abalado, e não sabia o que fazer, sabe? Porque você é o responsável lá e não tem ninguém para te instruir. Gerente não quer saber de você, se você erra eles tá te trocando. Então, foi muito difícil para mim.

... a gente tem que ficar conformando, mesmo tendo o medo, a gente tem que conformar com aquela situação. Só que chega um momento, tem um período que a gente tá abalado demais psicologicamente, ninguém agüenta! A perna tá formigando demais, porque fica muito tempo em pé, a mão numa suadeira... sua muito a mão. 
João percebeu que os problemas que viveu antes, continuavam afetando-o nesse retorno ao trabalho. Observou também que algumas oportunidades lhe foram negadas pelo estigma do afastamento do trabalho:

Ele [o gerente] encaixava outros, mas não me encaixava. Abria oportunidades, tinha oportunidades, mas ele preferia encaixar outros do que me encaixar, porque (...) já tinha acontecido essas coisas comigo e para eles é um erro que a gente podia tentar evitar.

Ele passou a sentir medo de realizar algumas tarefas, como conferir a presença de metais em bolsas ou pastas de clientes, sobretudo, quando estes reagiam agressivamente:

Os sintomas que eu tava, quando as pessoas, vinha agressiva, eu ficava gelado, esfriava todo. Às vezes, o gerente não gostava, sabe? Porque tinha que conferir o pessoal mesmo, quem tava com pasta, pedir para passar pelo local, ou seja, que tava com alguma coisa de metal dentro da pasta...

Ele se queixa também por nunca ter sido designado para um posto fixo depois que voltou do afastamento, dizendo que isso o incomodava. Sentia que a empresa não o queria mais trabalhando lá, que era visto como um inválido e que, portanto, poderia dar problemas a qualquer momento. Dessa forma, sua impressão era a de que tentavam forçar sua demissão:

...fica doido que o vigilante vai lá e pede as contas, porque já não agüenta mais a pressão. Eles vai jogando ele só nos setores ruins, os piores possíveis(...), é pro vigilante pedir conta, porque eles não querem suportar o vigilante lá, durante um ano, sabendo que ele tá abalado, ainda, porque isso fica marcado mesmo.

Assim, ele não conseguiu se readaptar ao trabalho depois do seu retorno. $\mathrm{O}$ fato de rever os mesmos lugares onde foi assaltado fez com que relembrasse os eventos e todas as reações que os acompanharam:

Eu voltei a trabalhar onde que aconteceu as coisas tudo. Foi trazendo um tanto de clima ruim, que eu fui voltando a ter as crises.

... a pessoa faz tratamento, vai passando os anos esquece um bocado, mas quando volta à ativa ele vai relembrando tudinho, as coisas que vai acontecendo, como aconteceu(...). Então, fica voltando tudo na cabeça da pessoa.

Dessa forma, ao retornar ao trabalho, continuou a apresentar os mesmos sintomas que levaram ao seu afastamento, como insônia, por exemplo. Ele relata que ainda não consegue dormir direito, mesmo tomando os remédios, pois fica pensando nos riscos do seu trabalho:

... a pessoa totalmente desabalada mesmo fica pensando: "oh, meu Deus, pode ser comigo" [ser morto em serviço]. "Será que vai ser comigo?". Dormir, não dorme mesmo. Fica lá "acesão" vinte e quatro horas horas (...). Eu fico pensando em tudo, "o que vai ser de mim?". Eu penso: "o que vai ser de mim? Eu preciso do serviço, que é arriscado é, mas eu preciso do serviço".

Diante de suas dificuldades na readaptação ao trabalho, João foi chamado à empresa para ser demitido. Explicaram que como ele não conseguiu se readaptar, mesmo tendo recebido muitas oportunidades, seria demitido, pois a empresa precisava reduzir o número de empregados. No entanto, ao ser encaminhado para o exame médico, foi detectado que não estava bem e que, portanto, não poderia ser demitido. Foi, então, que o afastaram pela segunda vez: 
Eu fiquei delirando muito, falava sozinho. Onde eu fui passar pelos exames e eles me falou que ia me mandar embora. Eu fui passar pela médica e a médica falou que não tinha condições de me mandar embora, tinha que me afastar de novo. Passei por duas psicólogas, um psiquiatra da empresa e todos eles me reprovaram, acharam que eu já tinha voltado a crise de novo.

Durante o período do seu segundo afastamento, João começou a freqüentar o $\mathrm{CERSAM}^{9}$, por indicação dos próprios médicos do INSS que o recebiam nas perícias. Lá, foi medicado e recebeu atendimento psicológico. Recebia remédios para dormir, dos quais não se lembra os nomes, e também injeção de haldol decanoato ${ }^{10}$, que agora toma de três em três meses. Desde então, permanece afastado, tendo procurado, há cerca de dois anos, o atendimento da equipe de psicologia da UFMG.

\section{Discussão do caso}

Tudo indica que João apresenta um quadro, o transtorno do estresse pós-traumático (CID-10, F-43.1), que é o único em torno do qual existe consenso entre as correntes que compõem o campo da saúde mental no trabalho. Trata-se, portanto, de um transtorno que os pesquisadores, independentemente de sua filiação teórica, admitem manter uma relação de causalidade direta com o trabalho.

Além disso, não se trata de uma afecção recente, pois já era estudada desde Freud, que analisou as neuroses de guerra. Naquele momento, ele dizia: "as neuroses de guerra são apenas neuroses traumáticas, que, como sabemos, ocorrem em tempos de paz também, após experiências assustadoras ou graves acidentes, sem qualquer referência a um conflito no ego" (Freud, 1996a, p. 226).

Ao final da primeira guerra mundial, muitos combatentes retornaram às suas casas apresentando quadros cujas origens eram desconhecidas. Os médicos militares os tratavam como alterações no sistema nervoso, porém os exames revelavam a ausência de alterações físicas. Ao analisar os soldados afastados, Freud percebeu sua relutância em retornar às suas funções militares e interpretou isso como uma defesa, ou seja, como uma forma de se resguardar das conseqüências de suas condições de trabalho:

Foi fácil, portanto, inferir que a causa imediata de todas as neuroses de guerra era uma inclinação inconsciente, no soldado, para afastar-se das exigências perigosas ou ultrajantes para os seus sentimentos, feitas sobre ele pelo serviço ativo. Medo de perder a própria vida, oposição à ordem de matar outras pessoas, rebeldia contra a supressão implacável da própria personalidade pelos seus superiores - eram estas as mais importantes fontes afetivas das quais se nutria a tendência para escapar da guerra (Freud, 1996b, pp. 227-228).

Para tal transtorno, Freud chegou a sugerir um tratamento com eletrochoque que, na época, parecia eficiente, porém, após esse tratamento, ao tentar-se fazer com que os combatentes retornassem para a guerra, os sintomas iniciais reapareciam, sugerindo que a realidade de trabalho era o fator principal na origem do quadro.

\footnotetext{
9 CERSAM: Centro de Referência em Saúde Mental, serviço substitutivo para o tratamento de pacientes portadores de sofrimento mental que pretende diminuir o número de internações e permitir que não sejam excluídos do convívio social.

10 O haldol é um neuroléptico do grupo das butirofenonas. Além da indicação para tratamento dos sintomas psicóticos, pode ser usado também para evitar enjôos e vômitos de qualquer origem, para controlar agitação, agressividade devido a outras perturbações mentais, ou ainda para tratar o distúrbio de Gilles La Tourette. O decanoato, que é a forma de ação prolongada, atua como pró-fármaco, liberando de forma lenta e estável o haloperidol do veículo.
} 
Cabe ressaltar que esse tipo de transtorno não foi detectado apenas em pacientes que tinham vivido a experiência da guerra, pois já era possível encontrar casos de vítimas de acidentes nas ferrovias, por exemplo, apresentando graves distúrbios mentais e cujo tratamento era desconhecido na época.

Vale destacar também que Freud (1996a) já havia percebido que nem todos os combatentes se tornavam neuróticos de guerra, apontando para as vulnerabilidades pessoais que também participam da gênese desse tipo de transtorno.

Não podemos igualmente deixar de ressaltar que esse quadro está bem descrito no manual de doenças relacionadas ao trabalho publicado pelo Ministério da Saúde em 2001. Segundo esse manual, o transtorno de estresse pós-traumático caracteriza-se por

uma resposta tardia e/ou protraída a um evento ou situação estressante (de curta ou longa duração) de natureza excepcionalmente ameaçadora ou catastrófica e que, reconhecidamente, causaria extrema angústia em qualquer pessoa (Ministério da Saúde do Brasil, 2001, p. 181).

Entre as situações potencialmente causadoras desse transtorno, o manual cita a tortura, o estupro, o terrorismo ou qualquer outro tipo de crime. Ou seja, "o paciente experimentou, testemunhou ou foi confrontado com um evento ou eventos que implicaram morte ou ameaça de morte, lesão grave ou ameaça" em relação à sua própria integridade física ou à de outros (Ministério da Saúde do Brasil, 2001, p. 181). Informa também que alguns tipos de trabalho favorecem mais o desenvolvimento do transtorno de estresse póstraumático, são aqueles que “(...) envolvem responsabilidade com vidas humanas, risco de grandes acidentes, como o trabalho no sistema de transporte ferroviário, metroviário e aéreo, o trabalho dos bombeiros etc." (p. 181).

Não é difícil perceber que o caso de João se enquadra perfeitamente nesse contexto, uma vez que foi exposto, durante os assaltos, a situações muito delicadas, que colocaram em risco sua vida e a de outras pessoas pelas quais se sentia responsável. Foi ameaçado de morte ou de lesão grave, sendo seu depoimento bastante revelador dos momentos de tensão e de nervosismo que viveu, caracterizando uma experiência eminentemente traumática. Além do assalto por si só já se configurar como um trauma, ainda teve o agravante de ter ocorrido várias vezes em um curto período. Ou seja, João foi exposto a um tipo de situação muito difícil, que se repetiu três vezes em um breve espaço de tempo. Essa infeliz coincidência só veio a agravar o quadro que se instalou depois. As acusações por parte de colegas e da empresa, insinuando que ele próprio teria alguma relação com os assaltos ocorridos em seu turno vieram se somar às conseqüências dos eventos traumáticos, contribuindo consideravelmente para o desenvolvimento do transtorno.

O manual de doenças relacionadas ao trabalho acima citado, além de outros manuais como o da CID-10 (Organização Mundial da Saúde, 1993), constatam que há situações que se configuram como traumáticas para a maioria das pessoas e, uma vez expostas a elas, há uma grande probabilidade de desenvolverem um quadro de TEPT. Dentre essas situações, os assaltos são citados, o que reforça nossa hipótese diagnóstica.

Mas, além das situações potencialmente traumáticas, os teóricos consideram também outras questões que devem estar presentes na caracterização do trauma. Sobre isso, Kapczinski e Margis apontam para os

diferentes aspectos [que] estão envolvidos na sintomatologia do TEPT, tais como a natureza do evento traumático, o número de exposições, a vulnerabilidade do indivíduo, a reação desse frente ao estressor, a rede de apoio após o evento, entre outros (Kapczinski \& Margis, 2003, p. 5). 
Pensando nesse último aspecto, parece-nos inegável o papel das acusações sofridas por João para a instalação do seu quadro. Vimos que ele se refere, com muito pesar, a toda experiência que viveu, mas lamenta, de forma ainda mais enfática, o fato de ter sido acusado de cumplicidade com os assaltantes. Relata que foi grande a pressão exercida pela empresa, ao tentar relacioná-lo com o ocorrido. Tudo indica que tal situação atuou como um agravante, podendo, inclusive, configurar-se como mais um dentre os diversos eventos estressores por ele vivenciados. Não há dúvida de que teve sua honestidade posta em xeque, o que pode ter contribuído para o delírio de cunho persecutório que apresentou durante a crise. Foi a partir dessas acusações que começou a apresentar os sintomas característicos do TEPT. Ficou evidente o medo exacerbado, levando-o inclusive a se recusar a sair de casa e até mesmo a deixar de dormir temendo que algo de ruim lhe acontecesse. Além disso, passou a não se relacionar mais com amigos, nem com a própria mãe, recolhendo-se dentro de casa e afastando-se do convívio social.

$\mathrm{Na}$ ocasião do nosso diagnóstico, apesar de já ter retomado alguns contatos sociais, esses ainda eram raros e pouco intensos, sendo restritos aos amigos do prédio que o visitavam em sua residência. Durante certo tempo, viu-se incapaz de lembrar-se dos fatos e descrevê-los com clareza e, quando conseguiu falar sobre eles, ao fazê-lo, voltava a apresentar as mesmas reações de antes, como o suor frio nas mãos e no corpo. Quando retornou à sua atividade profissional, não se sentiu à vontade com a situação, apresentando sintomas psíquicos e fisiológicos que expressavam seu desconforto frente a um contexto que só lhe trazia lembranças ruins. Até nosso último encontro, em novembro de 2004, não conseguia dormir, especialmente à noite, dizendo sentir medo e ficar agitado com pensamentos negativos sobre o futuro. Apresentou também idéias suicidas nos momentos mais críticos do seu quadro.

É importante observar como essas reações ficaram ainda mais exacerbadas quando ele retornou ao seu antigo emprego, voltando a conviver com a possibilidade de passar novamente por todos aqueles eventos. Isso o fez reviver os sentimentos e os temores despertados pelos assaltos. Além disso, podemos considerar também que a falta de tratamento adequado para a sua situação agravou o caso, pois cinco anos já se tinham transcorridos desde os eventos traumáticos e, até então, João não havia recebido qualquer diagnóstico sobre o mal que lhe acometia. Sendo assim, estava também desprovido de qualquer esclarecimento sobre as medidas que deveria tomar e sobre qual tratamento seguir. Enfim, não sabia o que se passava com si mesmo, como seu problema poderia ser tratado e se havia alguma possibilidade de revertê-lo.

João apresenta os sintomas descritos no manual de doenças relacionadas ao trabalho como característicos do TEPT. Ou seja, é fácil identificar seu quadro com a seguinte descrição que se encontra no referido manual:

o paciente apresenta uma sensação persistente de entorpecimento ou embotamento emocional, diminuição do envolvimento ou da reação ao mundo que o cerca, rejeição a atividades ou situações que lembram o episódio traumático. Usualmente, observa-se um estado de excitação autonômica aumentada com hipervigilância, reações exacerbadas aos estímulos e insônia. Pode ainda, apresentar sintomas ansiosos e depressivos, bem como ideação suicida (Ministério da Saúde do Brasil, 2001, p. 182).

Na ocasião do diagnóstico, ele dizia não ter mais idéias suicidas, mas afirmou que, em certas ocasiões, não conseguia ver outra saída para seus problemas. Houve também momentos em que parecia profundamente deprimido e outros em que manifestava sintomas graves, típicos da psicose, tais como delírios e alucinações. Este último dado nos obriga a explicar melhor nossa hipótese diagnóstica e o fato de afastarmos a possibilidade de um quadro de psicose. Ou seja, embora tenha apresentado sintomas psicóticos, João não parece enquadrar-se nesse diagnóstico. Ele apresentou, durante todo o curso dos atendimentos, a auto-crítica bastante preservada e uma percepção adequada da realidade, demonstrando estar 
em pleno exercício de suas faculdades mentais. Ele conseguia reconhecer a anormalidade de alguns episódios que viveu, sobretudo, os de conteúdo delirante, dizendo que algo muito grave deveria ter ocorrido para que se sentisse e agisse daquela forma.

A esse respeito, devemos ressaltar que os episódios dissociativos não são comuns, mas podem fazer parte do quadro de TEPT, assim como outros sintomas psicóticos (Figueira \& Mendlowicz, 2003). Usualmente, esses episódios têm relação direta com o evento estressor, mas podem ser usados também como uma forma de o indivíduo manter fora da consciência os pensamentos e os sentimentos penosos (Figueira \& Mendlowicz, 2003, p. 15). Nasio (1997) também afirma que “(...) a alucinação não é um fenômeno específico das psicoses. Ela pode se apresentar como um episódio fugaz, sob formas diferentes, no neurótico e no homem dito normal" (p. 27).

Desde o início, João mostrou-se fortemente incomodado com a suspeita levantada pela empresa e pelos colegas sobre sua ligação com os acontecimentos. Tudo indica que, ao se somar ao estresse provocado pelos assaltos, tal acusação levou-o a cogitar a hipótese de ser vítima de algum tipo de perseguição e até mesmo a duvidar de si mesmo. Não nos parece surpreendente, portanto, que seus delírios acabassem por ter um conteúdo persecutório. Ainda que nem sempre fossem diretamente relacionados com as situações que viveu - por exemplo, quando passou a se responsabilizar pelo fato de a lagoa da Pampulha estar secando -, o cunho persecutório permanecia. Finalmente, os episódios delirantes foram poucos e pontuais e datam do período em que João não recebeu qualquer forma de atendimento. ${ }^{11}$

É evidente que suas experiências anteriores ao trabalho como vigilante, devem ser consideradas, uma vez que teve de enfrentar situações adversas, como o abandono do pai ou a morte de sua avó durante a infância, além das responsabilidades precoces que teve de assumir junto à família. No entanto, ele parece ter lidado bem com tudo isso, conseguindo manter bom equilíbrio emocional durante todo o período anterior aos assaltos. Mesmo com o afastamento de seu pai, João conseguiu estabelecer vínculos com outras figuras, que preencheram, pelo menos em parte, a lacuna que ficou, como vimos com um dos seus padrastos e com a avó materna. Ao perder a avó, sofreu por um tempo, mas recuperou-se e continuou sua vida, como é esperado de um luto bem sucedido. Ele sempre conseguiu lidar bem com situações de pressão, mesmo quando era bem jovem, por exemplo, ao realizar tarefas que envolviam muita responsabilidade, como no transporte de valores. Soube também enfrentar dificuldades em outros empregos, como na ocasião em que foi convidado para trabalhar como office-boy e foi deslocado para a atividade de faxina. Decidiu sozinho sair dessa firma e procurar outra atividade por não concordar com a decisão da dona da empresa. $\mathrm{Na}$ sua vida pessoal, também se mostrou capaz de lidar com os problemas da família, assumindo, inclusive, responsabilidades no cuidado com os irmãos. Foi somente na ocasião dos assaltos e das suspeitas levantadas contra ele, já na condição de vigilante, que não suportou a pressão e acabou adoecendo.

$\mathrm{Na}$ ocasião das entrevistas, embora alguns sintomas apresentados por ele tivessem diminuído de intensidade, seu quadro permanecia basicamente o mesmo, apesar do acompanhamento psiquiátrico e psicológico que estava recebendo. Os medicamentos que usava são comuns nos tratamentos das psicoses, mas também utilizados nos quadros de TEPT (Bernik, Laranjeiras \& Corregiari, 2003). Assim, recebia assistência basicamente ambulatorial, indo ao CERSAM uma vez por mês para consultas psicológicas e a cada três meses para consultas psiquiátricas, quando lhe era ministrado o haldol decanoato. Portanto, embora seu diagnóstico não tivesse sido ainda completamente estabelecido, seu tratamento não era de todo inadequado. No entanto, como foi encaminhado para os atendimentos já tendo apresentado um episódio de crise delirante, passou a receber um tratamento de 
controle desse tipo de crise, que não mais se apresentou, mas o seu real problema, o transtorno de estresse pós-traumático, não era ainda considerado, nem pela psicologia nem pela psiquiatria. Concluímos que a falta de um diagnóstico mais preciso e, conseqüentemente, de um tratamento adequado devem ter contribuído para uma possível cronificação do seu problema. Margis (2003) admite também essa possibilidade quando diz que "as conseqüências de uma demora para diagnosticar apropriadamente o TEPT incluiriam o contínuo sofrimento do paciente e a eventual cronificação de seu quadro" (p. 20). Não é difícil, portanto, imaginar o prejuízo sofrido por João ao não receber o tratamento mais indicado para o seu quadro.

Cabe ressaltar ainda que o transtorno de estresse pós-traumático pode ser prevenido (ou amenizado) através da adoção de uma série de medidas nos contextos de trabalho. Tais medidas incluem a possibilidade de atendimento ao trabalhador, de forma que ele receba suporte psicológico imediatamente após a ocorrência do evento, o que pode contribuir para amenizar os danos causados pelo trauma.

Pode parecer que os assaltos, em contextos de trabalho como o de João, sejam eventos inevitáveis. No entanto, essa posição fatalista não nos parece a melhor forma de lidar com a questão. Em nosso entender, a conduta mais adequada deveria ser a de analisar minuciosamente tais contextos, a fim de verificar possíveis medidas de segurança a serem adotadas. A esse respeito, o manual do Ministério da Saúde é enfático ao dizer que

a prevenção do estado de estresse pós-traumático relacionado ao trabalho envolve uma complexa rede de medidas de prevenção de acidentes, segurança e promoção de condições de trabalho, incluindo condições organizacionais de trabalho que respeitem a subjetividade dos trabalhadores (Ministério da Saúde do Brasil, 2001, p. 183).

Vale ressaltar também que esse mesmo manual recomenda que, uma vez suspeita ou confirmada a instalação do quadro, deve-se providenciar a emissão de CAT (Comunicação de Acidente de Trabalho), documento que João procurava obter e, até o momento do atendimento, estava sendo negado.

Finalmente, é importante atentar ao fato de que as condições de trabalho enfrentadas pelos vigilantes não têm sido favoráveis e que, assim como João, outros colegas de profissão estão adoecendo e sendo afastados de suas atividades, conforme fica claro no seu depoimento:

Não é só eu que tô afastado nessa situação não. Só na minha empresa tem três ou quatro, por causa de assalto. Ficou na mesma situação que eu, não sabia o que fazer mais.

...um lá suicidou, pegou o revólver na cabeça e pá, deu um tiro na cabeça dele (...) Pegou o revólver e suicidou, deu um tiro na cabeça, de tanta pressão que ele sentiu.

Esse dado apenas reforça a necessidade de se atentar para as condições desfavoráveis encontradas no exercício dessa profissão e que deveriam ser mais compreendidas para se buscar, senão saná-las, pelo menos, minimizá-las.

\section{Considerações Finais}

Além de Freud, outros teóricos da psicologia e da psiquiatria já se dedicaram ao tema aqui tratado, procurando desvendá-lo, e, em especial, tratá-lo ou preveni-lo. Em junho de 2003, a Sociedade Brasileira de Psiquiatria publicou uma edição especial de sua revista, dedicada a esse tema, trazendo diversos enfoques diagnósticos e clínicos e destacando, mais 
uma vez, a necessidade de se divulgar informações sobre o assunto entre os profissionais de saúde e, especialmente, entre aqueles que atuam na área de saúde do trabalhador.

O diagnóstico de transtorno de estresse pós-traumático, não é, contudo, uma tarefa simples, uma vez que exige do clínico uma capacidade de investigar detalhadamente a história pregressa do paciente a fim de desvendar todo o processo de adoecimento, além do momento em que ocorreu o trauma que desencadeou os demais sintomas. Pois, como deve ter ficado claro, o TEPT vem acompanhado de diversos sintomas secundários, como depressão, medo exagerado, delírios persecutórios, revivescências do trauma, entre outros. Esses sintomas, em conjunto, caracterizam o transtorno, porém alguns deles, como a depressão, costumam ser mais rapidamente identificados pelos clínicos. No caso da detecção de apenas um dos sintomas, esse pode ser tratado como primário e os demais serem desconsiderados ou subestimados em sua importância na caracterização do quadro. É preciso, portanto, que se faça um diagnóstico detalhado, estabelecendo o nexo causal entre o conjunto de sintomas e o evento traumático para o que o problema possa ser tratado em toda sua abrangência.

Assim, como aponta Margis (2003), "as elevadas taxas de comorbidade podem diminuir as chances de que realize o diagnóstico de TEPT, pois, muitas vezes, quadros mais conhecidos são diagnosticados primeiramente" (p. 20). Por outro lado, Knapp e Caminha (2003) apontam para a dificuldade no tratamento, constatando que

é comum que pacientes com TEPT sejam tratados apenas em seus efeitos secundários, transtornos de humor ou outras formas de ansiedade, ao invés de serem tratados diretamente na matriz originária dos problemas (p. 35).

Um outro complicador consiste no tempo que, geralmente, se prevê para o surgimento do quadro. O manual da CID-10 afirma que, para se efetivar esse diagnóstico, a pessoa deve começar a apresentar os sintomas no prazo de seis meses após o evento estressante. De acordo com o referido manual, "esse transtorno não deve geralmente ser diagnosticado a menos que haja evidência de que ele surgiu dentro de seis meses após um evento traumático de excepcional gravidade" (Organização Mundial da Saúde, 1993, p. 146). No entanto, no que concerne a esse prazo, existem divergências entre os autores. MeshulamWerebe, Andrade e Delouya (2003), por exemplo, afirmam que as conseqüências do evento traumático podem aparecer tempos depois, até mesmo anos, o que coincide com o que Freud (1996a) chamava de período de "incubação". Eles ilustram esse dado dizendo que a guerra de 1973

entre Israel, Egito e Síria, gerou anos depois (15 a 25 anos), um problema grave, inclusive econômico para as autoridades israelenses. $\mathrm{O}$ serviço israelense de psiquiatria teve de emitir licenças médicas de trabalho e indenizações para veteranos acometidos por TEPT, anos depois da guerra (p. 38).

Infelizmente, a literatura aponta para uma dificuldade na remissão total dos sintomas, como pudemos confirmar no caso de João. Kapczinski e Margis (2003) trazem dados do NVVRS (National Vietnam Veterans Readjustment Study), no qual "foi constatado que 19 anos após a exposição ao combate, $15 \%$ dos veteranos de guerra permaneciam com TEPT". Além disso, trouxeram uma outra evidência importante sobre os bombeiros envolvidos em grandes incêndios na Austrália: 56\% apresentaram TEPT após 42 meses e 4\% continuaram apresentando o transtorno após oito anos (p. 4).

Há ainda pesquisas que tratam do que seria um evento traumático. Figueira e Mendiowicz (2003), por exemplo, discutem como há alguns anos, no DSM-III, eram considerados como traumáticos apenas eventos externos, como torturas e estupros. Eles argumentam que tal concepção é muito limitada, dizendo que a natureza do trauma depende 
também das características individuais e que deve ser levada em conta a resposta emocional dada a esse evento. Afirmam também que "a grande maioria das pessoas expostas a eventos traumáticos catastróficos não desenvolve TEPT, sugerindo que a resistência emocional média das pessoas é elevada" (p. 13). No entanto, ainda que consideremos as vulnerabilidades pessoais, não podemos nos esquecer da advertência feita pelos autores do já citado Manual de Doenças Relacionadas ao Trabalho, ao dizerem que

fatores predisponentes, tais como traços de personalidade ou história prévia de doença neurótica, podem baixar o limiar para o desenvolvimento da síndrome ou agravar seu curso, mas não são necessários nem suficientes para explicar sua ocorrência (p. 181).

De qualquer modo, é somente através de uma análise completa, envolvendo fatores biopsicossociais, que se consegue compreender adequadamente as razões pelas quais uma pessoa desenvolve TEPT, enquanto outra, submetida ao mesmo evento traumático, não apresenta o problema. Assim, não há como desconsiderar as características individuais e o modo pelo qual elas se articulam com os acontecimentos, fato também apontado por Freud ao tratar pela primeira vez do assunto.

Uma outra dificuldade nesse diagnóstico, como apontam Kapczinski e Margis (2003), reside no fato de muito de sua sintomatologia se assemelhar à sintomatologia da reação aguda ao estresse (CID-10, F-43.0), porém eles mesmos admitem que a duração do segundo quadro é consideravelmente menor, já que se trata de uma reação aguda, significando que os sintomas deverão persistir por, no mínimo, dois dias e, no máximo, quatro semanas (p. 4).

Assim, mesmo que se trate de um transtorno que não pode ser precocemente diagnosticado - pois sua instalação presume uma modificação progressiva dos sintomas -, não é difícil imaginar o custo humano que se tem em esperar seis meses para confirmar um diagnóstico de um paciente que está sofrendo. Além disso, quanto maior o atraso para se iniciar o tratamento, maior a probabilidade de os sintomas cronificarem, conforme deixa claro Margis (2003) ao dizer que "as conseqüências da demora para diagnosticar apropriadamente o TEPT, incluiriam o contínuo sofrimento do paciente e a eventual cronificação de seu quadro" (p. 20). Mas o essencial é que o diagnóstico não precisa estar confirmado para se dar início ao tratamento de uma pessoa que tenha passado por um evento potencialmente traumático. Pois, a partir do conhecimento do problema, já se sabe que a conduta correta é oferecer, imediatamente, atendimento psicológico aos indivíduos expostos a esse evento para que possam iniciar o processo de elaboração da experiência. Além disso, como foi visto no caso de João, os acompanhamentos psicológico e psiquiátrico, mesmo tardios, ajudou na redução de seus sintomas e, até mesmo, no desaparecimento de alguns.

Sobre, o uso do psicofármaco haldol e seu aparente sucesso na remissão do delírio de João, recorremos a Bernik, Laranjeiras e Corregiari (2003), quando afirmam que

As medicações podem ter diferentes papéis no tratamento: regular a resposta ao estresse e permitir ao indivíduo um retorno às suas atividades de vida normal; permitir uma melhor resolução da experiência traumática, em conjunto com o tratamento psicoterápico; controlar sintomas de ansiedade generalizada, hiperexcitação autonômica, psicoses breves, descontrole de impulsos e insônia; e evitar recaídas de condições comórbidas (p. 47).

Como podemos perceber, o uso de medicação não é incomum nesse tipo de transtorno e deverá ser receitada de acordo com os sintomas apresentados pelo paciente. Infelizmente, como os próprios autores colocam não há muitos estudos sobre a eficiência de psicofármacos no tratamento de TEPT, especialmente estudos relacionando antipsicóticos, como é o caso do haldol. Podemos, inclusive, pensar que, como os casos de TEPT não têm sido corretamente diagnosticados, os estudos sobre o tema ficam comprometidos. 
No caso aqui analisado, é possível concluir que o episódio de delírio consiste em um transtorno psicótico breve, que, segundo o manual DSM-IV, pode ocorrer de forma concomitante ao TEPT:

se o padrão de resposta sintomática ao estressor extremo satisfaz os critérios para outro transtorno mental (por exemplo, transtorno psicótico breve, transtorno conversivo, transtorno de depressão maior), esses diagnósticos devem ser dados ao invés de transtorno de estresse pós-traumático, ou em acréscimo a ele (American Psychiatric Association, 1994).

Além disso, o transtorno psicótico breve pode ter como um de seus subtipos o transtorno psicótico breve com estressor acentuado (DSM-IV, F-23.81), assim caracterizado pelo mesmo manual:

este especificicador pode ser anotado se os sintomas psicóticos se desenvolvem logo após e aparentemente em resposta a um ou mais eventos que, isoladamente ou em conjunto, seriam estressantes demais para praticamente qualquer pessoa em circunstâncias similares na cultura do indivíduo em questão (American Psychiatric Association, 1994).

Reconhecemos, no entanto, a dificuldade de estabelecer um diagnóstico preciso, apoiados apenas no relato do paciente a respeito de um evento ocorrido há alguns anos. Mas, baseados no depoimento do próprio João e no de sua mãe, não restou qualquer dúvida de que o delírio foi um episódio pontual na sua vida, não havendo indícios de estarmos lidando com um quadro típico de psicose.

Finalmente, cabe alertar que o TEPT é um transtorno que tem sido cada vez mais freqüente nos contextos de trabalho e, infelizmente, não tem sido dada a ele a devida importância. Sua prevenção na maioria dos casos é possível, em princípio, melhorando as condições de trabalho, de forma a evitar situações potencialmente traumáticas e, eventualmente, criando um sistema de acolhimento ao trabalhador que se envolva em alguma dessas situações.

É imperativo que haja maior quantidade de estudos não só deste, mas de outros transtornos desencadeados nos contextos de trabalho para que se possa atuar sempre com a perspectiva da prevenção e não apenas com a do tratamento de trabalhadores já incapacitados de exercer suas atividades produtivas.

\section{Referências}

American Psychiatric Association (1994). Diagnostic and statistical manual of mental disorders DSM-IV. Manual disponível na internet: http://virtualpsy.locaweb.com.br/dsm.php [25 julho 2007]

Bernik, M., Laranjeiras, M. \& Corregiari, F. (2003). Tratamento farmacológico de estresse póstraumático. Revista Brasileira de Psiquiatria, 25 (supl. 1), 46-50.

Organização Mundial da Saúde (1993). Classificação de transtornos mentais e de comportamento da CID-10: Descrições clínicas e diretrizes diagnósticas (D. Caetano, trad.). Porto Alegre: Artes Médicas.

Figueira, I. \& Mendlowicz, M. (2003). Diagnóstico do transtorno de estresse pós-traumático. Revista Brasileira de Psiquiatria, 25 (supl. 1), 12-16.

Freud, S. (1996a). Introdução à psicanálise e às neuroses de guerra. In Edição Standard Brasileira das Obras Psicológicas Completas de Sigmund Freud (vol. 27, pp. 221-226). Rio de Janeiro: Imago. 
Freud, S. (1996b). Introdução a psicanálise e as neuroses de guerra. Apêndice: Memorandum sobre o tratamento elétrico dos neuróticos de guerra. Edição Standard Brasileira das Obras Psicológicas Completas de Sigmund Freud (vol. 27, pp. 227-231). Rio de Janeiro: Imago.

Le Guillant, L. (2006). O Caso Marie L. In M. E. A. Lima (Org.), Escritos de Loius Le Guillat. (pp. 331-348). Petrópolis: Vozes.

Knapp, P. \& Caminha, R. M. (2003). Terapia cognitiva do transtorno de estresse pós-traumático. Revista Brasileira de Psiquiatria, 25 (supl. 1), 31-36.

Kapczinski, F. \& Margis, R. (2003). Transtorno de estresse pós-traumático: critérios diagnósticos. Revista Brasileira de Psiquiatria, 25 (supl. 1), 3-8.

Margis, R. (2003). Comorbidade no transtorno de estresse pós-traumático: regra ou exceção? Revista Brasileira de Psiquiatria, 25 (supl. 1), 17-20.

Meshulam-Werebe, D., Andrade, M. G. O. \& Deloya, D. (2003). Transtorno de estresse pós-traumático: o enfoque psicanalítico. Revista Brasileira de Psiquiatria, 25 (supl. 1), 37-40.

Ministério da Saúde do Brasil (2001). Doenças relacionadas ao trabalho: manual de procedimentos para os serviços de saúde. Brasília: Ministério da Saúde do Brasil.

Nasio, J. D. (1997). A alucinação e outros estudos lacanianos. Rio de Janeiro: Zahar.

\section{Endereço para correspondência}

juliadorigo@gmail.com, bethalima@terra.com.br

Recebido em: 30/10/2006

Revisado em: 02/08/2007

Aprovado em: 16/08/2007 